\title{
Kasey McCall-Smith, Jan Wouters and Felipe Gómez Isa (eds). 2019. The Faces of Human Rights, Oxford: Hart Publishing. 356 p.
}

doi: http://dx.doi.org/10.18543/djhr.1798

On the occasion of the 70th anniversary of the Universal Declaration of Human Rights, numerous initiatives were launched for its celebration, including events, conferences and publications, all seeking to commemorate its validity. Many of these publications, such as the one coordinated by Carol Proner, Héctor Olasolo, Carlos Villán Durán, Gisele Ricobom and Charlotth Back (2018), or the book directed by Carla Ferstman, addressed this tribute from the analysis of the evolution of the institutions and the normative body of the international system for the protection of human rights originating from the Declaration. However, among all of these, the publication coordinated by Kasey McCall, Jan Wouters and Felipe Gómez incorporates a different and necessary perspective. It reminds us that the milestone achieved with the Declaration was the result of the effort and struggle of many faces: men and women who, throughout history and from different parts of the world and backgrounds, made their contribution to the struggle for the freedom and dignity of people. The Faces of Human Rights highlights the stories of 32 people (20 men and 12 women), relevant in the history of Human Rights, described by a group of academics, members of the Association of Human Rights Institutes (AHRI), and supported by strong research and documentary review. The group of people who have contributed to this work belong to different institutes from the aforementioned association and stand out for their activism and academic trajectory. Therefore, in addition to the coordinators of the work, it is worth mentioning the contribution of outstanding authors with a solid academic background such as Manfred Nowak, Eva Maria Lassen, Wolfgang Benedek or Elizabeth Salmon, who contribute to an inter-institutional and interdisciplinary review of developments in the protection of human rights. Nonetheless, in this book have also participated junior researchers with promising careers, which augurs a good future for the Association and for the field of human rights protection. Special mention should be given to the careful editing of the publication and the images and drawings that go along with each biographical note, literally giving faces to the personal stories of these 32 great references of history.

The book is structured into an introductory chapter and five parts that compile the stories of different figures, from different backgrounds 
(academia, civil servants, civil society or human rights activists), who played a key role in the field with their work and dedication. As the authors themselves point out in the introduction, finding a coherent methodological criterion to justify the selection of the personalities to be included in the publication was one of the main challenges of this work. The most important hurdle was both bringing together the criteria and preferences of the contributors, all of them coming from different disciplines and backgrounds, and keeping a common thread in line with the main objective of the publication, namely: "to recall the reasons why human rights are so essential to the post-Second World War peace and how the flame that is human dignity continues to burn and move individuals to act in its pursuit» (p. 2).

Yet, the final list of outstanding personalities and the chronological structure, together with the use of the Declaration itself as the backbone of the publication, represent an appropriate approach. It makes The Faces of Human Rights an outstanding and innovative work, which reminds us that the history of human rights is linked to those people who have devoted their lives to its promotion.

At a time when people who dedicate their efforts to the promotion and protection of human rights face serious threats and risks every day, the focus adopted in this work is not only relevant but necessary. Only in 2018, the same year that the seventy-year anniversary of the Declaration was celebrated, 321 human rights defenders were killed (Front Line Defenders, 2018), showing the relevance of personal struggles of human rights activists and the importance of individual battles for the common good. The individuals featured in The Faces of Human Rights share with today's defenders and activists their commitment and personal belief in the defence of freedom and human dignity, and have become references and cornerstones of contemporary history.

As mentioned above, the Declaration is used by the coordinators of this work as the backbone and assembling axis of this compilation of biographical reviews. Thus, the first part of the book collects the story of six personalities, four men and two women, who lived prior to the Declaration, and laid the foundations for the current human rights protection system. Although the figures gathered in this first part date back to centuries before the Declaration was approved, there is no doubt that Bartolomé de las Casas, John Locke, Olympe de Gouges, Mary Wollstonecraft, Henry Dunant and Mahatma Gandhi as presented by Ignacio de la Rasilla, Cristina de la Cruz-Ayuso, Teresa Pizarro and Helena Pereira, Dolores Morondo, Joana Abrisketa and George Ulrich respectively, marked an essential path towards the milestone of the 
Universal Declaration of Human Rights. The defence of the Amerindians during the Spanish colonization, the fight for freedom, tolerance, equality, attention to the wounded in conflict, or non-violent resistance promulgated by the protagonists included in this first part established, as stated by the coordinators in the introduction, the foundations of Human Rights from the Natural Law and equality.

The second part of this work moves chronologically closer to the drafting of the Declaration of Human Rights and highlights five key people (four men and one woman) who played an essential role in the drafting process. As on other occasions across History (the Bill of Rights in England after the revolutionary period between 1642 and 1689, the Declaration of the Rights of man and the citizen after the French Revolution -1789-1799-, or the Bill of Rights of the US preceded by the Virginia Bill of Rights, after the American Revolution of 1776) the Universal Declaration of Human Rights was strongly conditioned by the two World Wars. The same applies to the protagonists included in this second part conditioned by the violent beginning of $20^{\text {th }}$ century. It marked their commitment to the drafting and institutionalization of the Human Rights protection system. Hence, as Eva María Lassen, Adam Redzik, Anya Luscombe and Barbara Oomen, Jan Wouters and William Schabas put forward in this second part, Hersch Lauterpacht, Raphael Lemkin, Eleanor Roosevelt, René Cassin and John Peter Humphrey played a fundamental role in the elaboration and adoption of the Declaration which marked a turning point in the protection of Human Rights. The third part focuses on people who fought for the defense of human rights in specific national or regional contexts in the post Declaration era: Rosa Parks and Martin Luther King against racial segregation in the US, Nelson Mandela against South African Apartheid, Angelica Mendoza de Ascarza and her fight against enforced disappearances in Peru, Faith Bandler, Rigoberta Menchú and Victoria Tauli-Corpuz with their struggle for indigenous peoples in Australia, Guatemala and the Philippines, as well as Asma Jilani Jahangir and her work in Pakistan. The work of all these people transcended their national contexts and reached important milestones for the universal protection of human rights. The authors of their respective biographical reviews (Kasey McCallSmith, Vivek Bhatt, Narnia Bohler-Muler, Michelle Burgis-Kasthala, Elisabeth Salmón, Felipe Gómez Isa, Davinia Gómez-Sánchez and Mikel Mancisidor) highlight the importance of acts of individual resistance: the charismatic leadership of the social movements, the struggle for freedom and equality and for obtaining accountability for serious human rights violations, for humanity as a whole. 
One of the quotations highlighted by Davinia Gómez-Sánchez in her tribute to Victoria Lucia Taulí-Corpuz perfectly illustrates the link between the third part, focused on the struggle in particular contexts, and the fourth part of the work, devoted to people who worked in for the protection of human rights using the system established by the declaration, politics and international activism: «in order to secure our rights, we would have to deal with the international system» (p. 189).

This connection demonstrates not only the good work of the book coordinators in the compilation and structuring of figures and authors, but also the intimate relationship between individual struggles and the effectiveness of the universal system for the protection of human rights.

Therefore, the fourth part of the book underlines the work of eight other personalities (seven men and one woman) in the use of international activism for the promotion of human rights. Dimitrios Kagiaros and Stefaan Smis analyze the work of Sean MacBride and Peter Benenson, both illustrious international activists and founding members of Amnesty International. Antoine Busyse and Roman Wieruszewski explain the contribution of two important politicians of the $20^{\text {th }}$ century who used their position to achieve the protection of minorities and the humanization of politics: Max van der Stoel and Tadeusz Mazowiecki. They are followed by Jimmy Carter and Peter Leuprecht's reviews prepared by Stohl and Wolfgang Benedek, two other referents of the fervent defense of the commitment to human rights, the first from the US, and the latter from Europe. This fourth part ends with the Elaine Webster and Rebeca Smyth tribute to Juan E. Méndez and Mary Robinson, two key referents who have played an important role in the United Nations system for the defense of Human Rights.

The faces of Human Rights concludes with a fifth part dedicated to contemporary activists, two women and three men, who demonstrate the need for the continuity of the struggle for the sake of freedom and human dignity. Hence, the example of Radhika Coomaraswamy, Gerard Quinn, David Kato, Malala Yousafzai and Theo van Boven illustrates the validity of the discourse and values set by the Universal Declaration and the permanent need for individuals' commitment to social transformation. The figures chosen by Ingrid Westendorp, Anna Bruce and Anna Lawson, Aimar Rubio Llona, Gamze Erden Türkelli and Manfred Nowak show that in the s. XXI there are still activists and professionals who dedicate their lives to the promotion of social justice and human dignity. 
Such is the situation that human rights are at the heart of the Sustainable Development Goals (SDGs) that make up the Sustainable Development Agenda agreed on in 2015, and which seeks to reach a society with no poverty, egalitarian and respectful of the planet in 2030. To achieve these 17 goals and 167 targets, human rights are essential, as it is the commitment of people who continue the battle waged by the faces highlighted in The Faces of Human Rights. Like the people featured in this work, all of them from different countries, ages, genders, races and social backgrounds, we still need young people like Greta Thunberg and her fight against climate change, Befeqadu Hailu and his defense of freedom of expression, Nadia Murad and her denunciation of the atrocities committed by ISIS, Mohamed Yunus with his promotion of economic and social opportunities for poor people, or Aminetu Haidar and her peaceful resistance to human rights violations in the Western Sahara. These activists and Human Rights defenders not only lengthen the list of faces that work to materialize the values contained in the Declaration, but continue to give voice to injustices and abuses.

For all the above, the work coordinated by Kasey McCall, Jan Wouters and Felipe Gómez is an innovative and successful work that reminds us that institutional and regulatory progress, nor even State and institutional commitment, is not possible without the work performed by people who day by day stand up and raise their voices to defend human rights.

\section{References}

Proner, Carol, Héctor Olasolo, Carlos Villán Durán, Gisele Ricobom and Charlotth Back. 2018. $70^{\circ}$ aniversario de la Declaración Universal de Derechos Humanos.La protección internacional de los derechos humanos en cuestión, Valencia: Tirant lo Blanch.

Ferstman, Carla, and Tony Gray (eds.). 2018. Contemporary Human Rights Challenges: The Universal Declaration of Human Rights and Its Continuing Relevance. London: Routledge.

Front Line Defenders. 2018. Front Line Defenders. Global Analysis 2018. Dublin: Front Line. Disponible en: https://www. frontlinedefenders.org/ sites/default/files/global_analysis_2018.pdf

María López Belloso Universidad de Deusto 


\section{Copyright}

Deusto Journal of Human Rights / Revista Deusto de Derechos Humanos is an Open Access journal; which means that it is free for full and immediate access, reading, search, download, distribution, and reuse in any medium only for non-commercial purposes and in accordance with any applicable copyright legislation, without prior permission from the copyright holder (University of Deusto) or the author; provided the original work and publication source are properly cited (Issue number, year, pages and DOI if applicable) and any changes to the original are clearly indicated. Any other use of its content in any medium or format, now known or developed in the future, requires prior written permission of the copyright holder.

\section{Derechos de autoría}

Deusto Journal of Human Rights / Revista Deusto de Derechos Humanos es una revista de Acceso Abierto; lo que significa que es de libre acceso en su integridad inmediatamente después de la publicación de cada número. Se permite su lectura, la búsqueda, descarga, distribución y reutilización en cualquier tipo de soporte sólo para fines no comerciales y según lo previsto por la ley; sin la previa autorización de la Editorial (Universidad de Deusto) o la persona autora, siempre que la obra original sea debidamente citada (número, año, páginas y DOI si procede) y cualquier cambio en el original esté claramente indicado. Cualquier otro uso de su contenido en cualquier medio o formato, ahora conocido o desarrollado en el futuro, requiere el permiso previo por escrito de la persona titular de los derechos de autoría. 